African Crop Science Journal by African Crop Science Society is licensed under a Creative Commons Attribution 3.0 Uganda License. Based on a work at www.ajol.info/ and www.bioline.org.br/cs DOI: http://dx.doi.org/10.4314/acsj.v25i2.9

\title{
PARTICIPATORY SELECTION OF MUNGBEAN GENOTYPES IN UGANDA
}

\author{
E.K. MBEYAGALA, N. KWIKIRIZA', R. AMAYO, J.R. OMADI, D. OKWANG and J.E.P. OBUO \\ National Agricultural Research Organization (NARO), National Semi Arid Resources Research Institute \\ (NaSARRI), P. O. Box 56, Soroti, Uganda \\ ${ }^{1}$ International Potato Center (CIP), P. O. Box 22274, Kampala, Uganda \\ Corresponding author: kmbeyagala@gmail.com
}

(Received 17 January, 2017; accepted 29 May, 2017)

\begin{abstract}
Production and utilisation of mungbean (Vigna radiata) in Uganda is constrained by unavailability of improved and farmer-preferred varieties. The objective of this study was to document and assess farmers' preference for mungbean using eleven introduced genotypes. We captured twenty five traits during farmer interviews out of which six traits were identified (through group discussions) as the most often used by farmers when selecting the best mungbean genotypes. The traits were; yield, overall performance, seed size, seed colour, marketability and early maturity. Nine out of eleven introduced genotypes were selected during on-farm trials using the six traits. The selected genotypes were; Filsan, Mauritius, Sunshine, VC6137B14, VC61485012, VC6153B20, KPS1, VC6173B10 and VC63724560. The selected genotypes were early maturing (60-70 days), with large green or greenish yellow seeds. However, two late maturing (80-90 days) and small seeded genotypes; Blackgram and Yellowgram were rejected by farmers despite yielding higher (1459 and $1035 \mathrm{~kg} \mathrm{ha}^{-1}$, respectively) than other genotypes. This study showed that farmers use a combination of traits when choosing a mungbean genotype for adoption and these should be considered in mungbean improvement. Chi square tests of independence showed that there were no significant differences in genotype choices based on gender $\left(\chi^{2}=2.5419, \mathrm{P}\right.$-value $\left.=0.97\right)$. However, there were significant genotype preference differences between eastern and northern regions $\left(\chi^{2}=\right.$ $22.34, \mathrm{P}<0.01)$. It is possible to develop new genotypes that are acceptable to both men and women since they have no specific trait preferences.
\end{abstract}

Key Words: Gender, preferences, Vigna radiata

RÉSUMÉ

La production d'haricot mungo (Vigna radiata) en Uganda est faible à cause du manque de variétés améliorées. L'objectif de cette étude était d'évaluer les préférences des producteurs sur les génotypes introduits du haricot mungo. Vingt cinq traits étaient utilisés pendant les interviews; toutefois, l'évaluation de l'importance de ces traits n'était pas efficace puisqu'il y avait une faible discrimination parmi les personnes interrogées. De plus, l'implication des producteurs dans les groupes de discussion a généré six traits (le rendement, la performance générale, la taille de la graine, la couleur de la graine, le potentiel commercial et la précocité de la maturité) qu'ils ont souvent utilisés dans l'évaluation des génotypes du haricot mungo. Durant les essais dans les champs, les producteurs ont préféré neuf des genotypes introduits; à savoir, Filsan, Mauritius, Sunshine, VC6137B14, VC61485012, VC6153B20, KPS1, VC6173B10 et VC63724560. Les génotypes sélectionnés étaient de maturité précoce (60 - 70 jours); avec de grosses vertes ou verdâtre graines. Néanmoins, deux génotypes (gramnoir et gramjaune) étaient rejetés par les producteurs malgré leur haut rendement (1459 et $1035 \mathrm{kgha}^{-1}$; respectivement) comparés aux autres génotypes. Gramnoir et gramjaune étaient de maturité tardive (80-90 jours); de plus petites graines noires et jaunes respectivement. Cette étude a montré que, bien que le rendement soit un trait important, 
il ne constitute pas le seul critère que les producteurs utilisent quand ils sont entrain de sélectionner les génotypes pour adoption. Les tests d'indépendance de Chi-carré n'ont révélé aucune différence significative dans le choix des génotypes basé sur le genre $\left(\dot{\div}^{2}=2,5419, \mathrm{P}\right.$-value $\left.=0,97\right)$. Néanmoins, il y avait eu de differences significatives entre les régions de l'Est et du Nord du pays sur les préférences des génotypes $\left(\chi^{2}=22,34, \mathrm{P}<0,01\right)$. Il est possible de développer de nouveaux génotypes qui sont acceptables chez les hommes et les femmes car ils n'ont pas de préférences de traits spécifiques.

Mots Clés: Genre, préférences, Vigna radiata

\section{INTRODUCTION}

Mungbean, Vigna radiata $($ L.) Wilczek, is an important food and cash crop in Uganda. Farmers, especially in eastern and northern regions use it as a source of proteins, micronutrient, income and as emergency crop in times of crop failures; as well as supplementary animal feed for fattening livestock (Mogotsi, 2006). Mungbean improves soil fertility through biological nitrogen fixation and is, therefore, used in crop rotations, mixed cropping and alley cropping systems (Heuzé et al., 2015).

Farmers in these regions, mainly grow landraces, whose productivity is low; estimated at less than $300 \mathrm{~kg} \mathrm{ha}^{-1}$; thus making cultivation of the crop less profitable (Ibedo, 2014). There are ongoing research efforts in the country aimed at developing and selecting high yielding mungbean varieties. However, for these efforts to be successful, farmer and consumer preferences need to be considered. Farmers usually consider numerous characteristics for variety selection; for instance yield, marketability, grain size, grain colour, taste, pests and disease resistance (Mekbib, 1997). Having a clear understanding of the research needs (priorities of small scale farmers in various agro-ecological conditions and socio-economic contexts) is critical to the selection of varieties that will have long term adoption by farmers in such settings (Sperling et al.,1993). The objective of this study was to explore farmers' acceptance criteria and preferences for mungbean; and their use for selection among a group of introduced mungbean genetic materials in Uganda.

\section{MATERIALS AND METHODS}

This study was carried out in two phases; in phase I, individual farmer interviews and focus group discussions were used to document, analyse and compare the traits that mungbean farmers value or consider important. The second phase involved conducting on-farm participatory selection and performance evaluation trials for the new mungbean genotypes. The introduced genotypes evaluated were advanced breeding lines developed by the World Vegetable Center (WorldVeg) also known as Asian Vegetable Research and Development Center (AVDRC) based in Taiwan. These genotypes have superior traits such as high yield potential and large seed size compared to the local genotypes.

Phase II generated a list of characteristics that were regarded highly by mungbean farmers, and these were used in rating of the genotypes for acceptability. In phase II, eleven advanced breeding lines obtained from AVDRC and one local check were used (Table 1). The local check (known as "Echoroko lodidi") included in this study is the most popular variety grown by farmers in eastern and northern Uganda.

Phase I: Mungbean traits. To characterise mungbean traits that farmers use to describe, recognise and select mungbean traits, individual interviews were held in Amuria and Soroti districts. In Amuria district, interviews were held in Orungo and Akeriau sub-counties; while in Soroti district, it was conducted in Gweri sub-county. The farmers who 
TABLE 1. List of genotypes evaluated in on-farm in eastern Uganda

\begin{tabular}{lll}
\hline Genotype name & Species & Source \\
\hline Blackgram & Vigna mungo & World Vegetable Centre \\
Filsan & Vigna radiata & World Vegetable Centre \\
KPS 1 & Vigna radiata & World Vegetable Centre \\
Echoroko lodidi (check) & Vigna radiata & National Semi Arid Resources Research Institute \\
Mauritius & Vigna radiata & World Vegetable Centre \\
Sunshine & Vigna radiata & World Vegetable Centre \\
VC6137B14 & Vigna radiata & World Vegetable Centre \\
VC61485012 & Vigna radiata & World Vegetable Centre \\
VC6153B20 & Vigna radiata & World Vegetable Centre \\
VC6173B10 & Vigna radiata & World Vegetable Centre \\
VC63724560 & Vigna radiata & World Vegetable Centre \\
Yellow mungo & Vigna radiata & World Vegetable Centre \\
\hline
\end{tabular}

participated in the interviews either belonged to or were associated with a farmer group involved in mungbean production and marketing for at least two seasons.

A total of 52 respondents were interviewed using a semi structured questionnaire. In the first part of the interviews, respondents were asked to choose the most preferred trait category for eight different mungbean traits as listed by IBPGR (1980). The traits included growth habit (erect, semi-erect or spreading), climbing tendency (present or absent), flowering pattern (continuous or discontinuous), pod position (above or within/ below canopy), pod colour (brown or black), pod length (short or long), pod size (small or large), seed colour (yellow, greenish yellow, green, brown and black), and seed luster (dull or shiny).

In the second part of the interview, respondents were asked to rate the importance of 25 different mungbean traits (including the eight traits used in part one above) on a 1-3 scale ( $1=$ very important, $2=$ less important, $3=$ not important) modified from Asfaw et al, (2012). For some of the mungbean traits that respondents could not easily describe or differentiate, samples were displayed to help guide them in filling out the questionnaires. From the data descriptive statistics such as frequencies and percentages of respondents considering a particular trait as important were calculated using R Software, Version 3.3.1 (R Core Team, 2016). Traits with the highest frequencies were ranked the most important; while those with least scores were considered of less importance to the farmers.

In addition to the individual interviews, focus group discussions (FGDs) were held with farmers to identify six out of the twenty five traits that they most often used for evaluating mungbean genotypes. The frequency with which farmers mentioned a trait was recorded.

Phase II: On-farm participatory variety selection. During phase II of the study, participatory on-farm trials were used to assess and select newly introduced mungbean genotypes for six of the twenty five traits identified in phase 1 . The six traits were yield, overall performance, marketability, grain colour, seed size and early maturity. The trials were set up in Kumi and Soroti districts (eastern region), Kitgum and Aleptong districts (northern region). In each district, three farmers were identified with the help of district agricultural extension workers, to host the onfarm participatory trials. Each farmer was treated as a replicate, hence, there were three replicates per district. The trials were researcher designed (RCBD), but managed by 
farmers/farmer groups. Planting was done jointly by the research team and farmers.

The study was set up during the first and second rainy seasons of 2015. A total of twelve mungbean genotypes (11 introduced and one check) were assessed. The introductions were from the World Vegetable Center (WorldVeg); while the check genotype used was ("Echoroko lodidi"), a popular landrace in eastern and northern Uganda.

The selection and evaluation processes were carried out close to physiological maturity for early maturity and overall preference traits; while yield, seed colour, seed size and marketability trait evaluations were done after harvest. In all assessments, the introduced genotypes were rated against the local check, on a scale of 1-5 where; $1=$ much better than check variety (local type); $2=$ a little better than check variety; $3=$ same as check variety; $4=$ a little worse than check variety $;=$ much worse than check variety. The six traits for evaluating the genotypes were discussed with the participants with description of plants in the field trials until each farmer clearly understood how to rate the genotypes for each trait based on the scale. Farmers were also asked to indicate which genotypes they would plant the following season. During the assessment, genotypes were identified by plot numbers rather than by their names in order to avoid bias; as suggested by (Kapinga et al., 2003). After harvest and threshing, yield was recorded per plot and this was extrapolated to yield per hectare. Information on the gender (male/female/youth) of farmers that rated the new mungbean genotypes for the six traits during on-farm trials was also recorded.

Data analysis. Analysis of qualitative data (genotype rating) from on-farm participatory trials was done using ordinal logistic regression; while quantitative grain yield data analysis was done using descriptive statistics as implemented in R Software Version 3.3.1 ( $\mathrm{R}$ Core Team, 2016). Ordinal logistic regression analysis was carried out as described by Coe (2002a, b). For logistic regression analysis, the check genotype was used as reference. The log odds ratios show the chance of genotype being rated "much better" for a particular trait rather than being rated "much worse" as compared to the reference genotype (local check). Thus, a higher log odds ratio for a genotype shows that it is more likely to be rated as much worse for that trait than another genotype. A Chi square test of independence was conducted (at $\alpha=0.05$ ) to determine the association between farmers' genotype preferences, gender and the region where the farmers were located.

\section{RESULTS}

Farmer's selection criteria. From the individual interviews in phase I, majority of farmers preferred varieties with large, straight, long and black (at maturity) pods that were above the canopy (Fig. 1). In addition, they preferred varieties with erect growth habits; and varieties with a continous flowering pattern, green seeded with a shiny luster and non-climbing. Majority (> 70\%) of the respondents found most the traits to be very important, except for three traits; seed luster, fodder yield and climbing tendency, which were considered less important (Table 2). Grain yield and Pod load had the highest frequency from all the respondents. During focus group discussions, six traits out of twenty five were chosen as the most often used for evaluating mungbean genotypes. These traits included seed size, seed colour, marketability, yield, overall performance and early maturity. These traits were, therefore, used to rate the new genotypes genotypes during on-farm participatory phase.

Farmer rating of genotypes. Farmer rating of the eleven introduced mungbean genotypes against local check (on 1-5 scale) for the six traits showed that all genotypes were preferred, except Blackgram and Yellowgram 
Participatory selection of mungbean genotypes

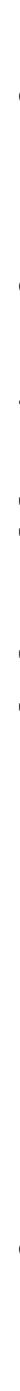

Scale

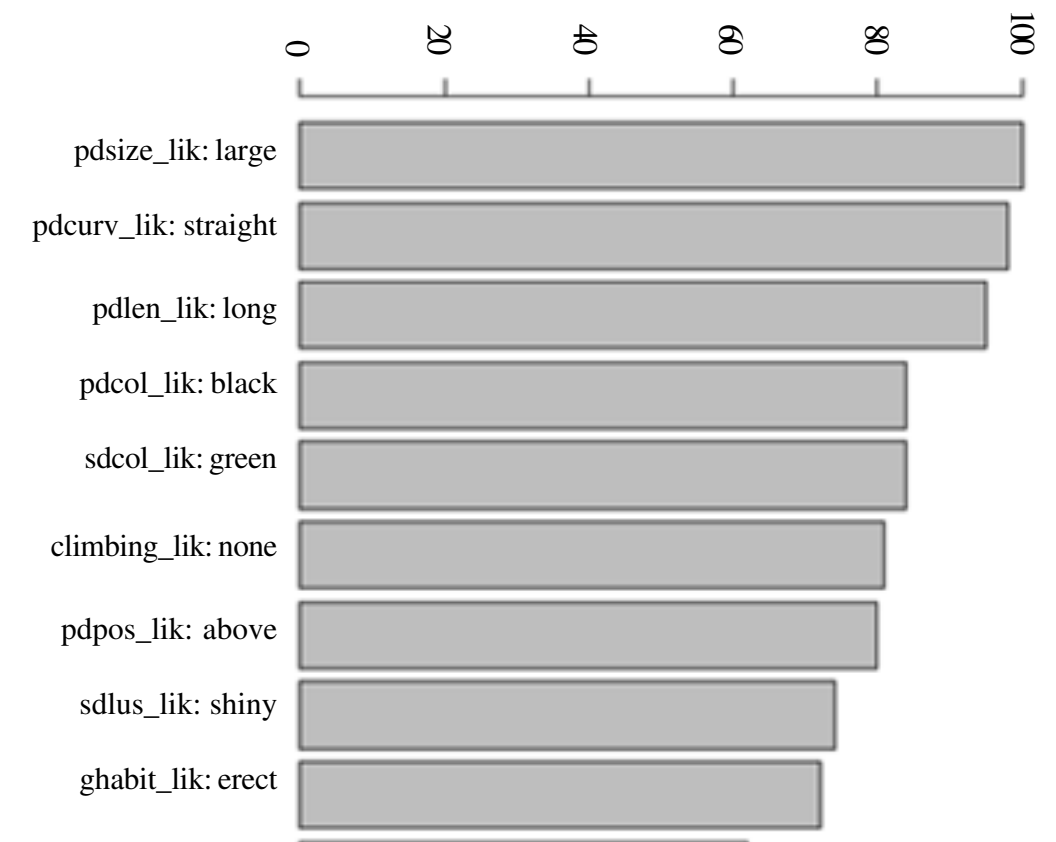

flwpat_lik: continuous

flwpat_lik: discontinuous

sdlus_lik: dull

pdpos_lik: below

climbing_lik: present

ghabit_lik: semi-erect

pdcol_lik: brown

ghabit_lik: spreading

pdlen_lik: short

sdcol_lik: brown

sdcol_lik: greenish yellow

sdcol_lik: yellow

climbing_lik: other

pdcurv_lik: curved

sdcol_lik: black 
TABLE 2. Mungbean traits and rating of their importance by farmers in Uganda

\begin{tabular}{|c|c|c|}
\hline Trait & $\mathrm{n}$ & Percent \\
\hline \multicolumn{3}{|l|}{ Most important } \\
\hline Grain yield & 52 & 100 \\
\hline Pod load & 52 & 100 \\
\hline Grain taste & 51 & 98 \\
\hline Maturity earliness & 50 & 96 \\
\hline Pod size & 49 & 96 \\
\hline Flowering pattern & 49 & 94 \\
\hline Cook ability & 49 & 94 \\
\hline Pod length & 48 & 94 \\
\hline Growth habit & 47 & 92 \\
\hline Seed colour & 47 & 90 \\
\hline \multicolumn{3}{|l|}{ Important } \\
\hline Weevil resistance & 46 & 88 \\
\hline Pod curvature & 45 & 88 \\
\hline Pod shattering resistance & 45 & 87 \\
\hline Lodging resistance & 44 & 85 \\
\hline Pod position & 43 & 84 \\
\hline Drought resistance & 43 & 83 \\
\hline Pod colour & 43 & 83 \\
\hline Disease resistance & 42 & 81 \\
\hline Pest resistance & 42 & 81 \\
\hline Uniform mataurity & 42 & 81 \\
\hline Seed size & 42 & 81 \\
\hline Leaf retention at maturity & 41 & 79 \\
\hline \multicolumn{3}{|l|}{ Least important } \\
\hline Seed lustre & 35 & 67 \\
\hline Fodder yield & 33 & 63 \\
\hline Climbing tendency & 15 & 29 \\
\hline
\end{tabular}

(Figs. 2 and 3). Blackgram and yellowgram had higher log odds ratios for most of the six traits, an indicator that they were rated as "much worse" and therefore not preferred compared to the local check. The nine remaining genotypes had lower and relatively similar log odds ratios for marketability, early maturity, seed size and seed colour but differed for yield and overall performance traits.

The most farmer selected genotypes for planting in the coming seasons were Filsan, followed by VC63724560, VC6153B20, VC6137B14, VC61485012, Mauritius, and Sunshine (Fig. 4). The least selected genotypes were Blackgram and Yellowgram. Blackgram has small black coloured seeds; while Yellowgram has small yellow coloured seeds. Both genotypes are late maturing (80-90 days). According to Chi Square test, there were significant differences in in preferences for mungbean genotypes $\left(\chi^{2}=22.34, \mathrm{P}<0.01\right)$ between farmers in the northern and eastern Uganda. However, there were no significant differences in choices of mungbean genotypes between male and female $\left(\chi^{2}=2.5419\right.$, $\mathrm{P}>0.05$ ).

There were differences in yield of mungbean genotypes from on-farm in both seasons with Blackgram and Yellowgram performing better than the rest of the entries (Table 3).

\section{DISCUSSION}

Farmer selection criteria. Mungbean farmers listed twenty five different traits that guide their selection decisions on mungbean genotypes for adoption (Table 2). With the exception of three traits (seed lustre, fodder yield and climbing tendency) all other traits were considered either as important or most important by the respondents. Some of the traits that were rated by respondents as most important or important such as pod load, pod size, pod length and seed size are proxies that farmers use in estimating yield potential (Table 2 ). Out of the twenty five different traits, farmers chose six traits (yield performance, overall performance marketability, seed colour, seed size, and earliness to maturity) that they often use when evaluating mungbean genotypes for adoption. Therefore, while farmers consider many traits, there are a few traits that they often use and these need to be identified. Previous studies by Kamara et al. (2010) working on cowpea and Asfaw et al. (2012) working on common beans reported similar findings of farmers using a combination of a few traits when evaluating new genotypes.

Farmer rating of genotypes. Most of the introduced genotypes were rated highly by the 


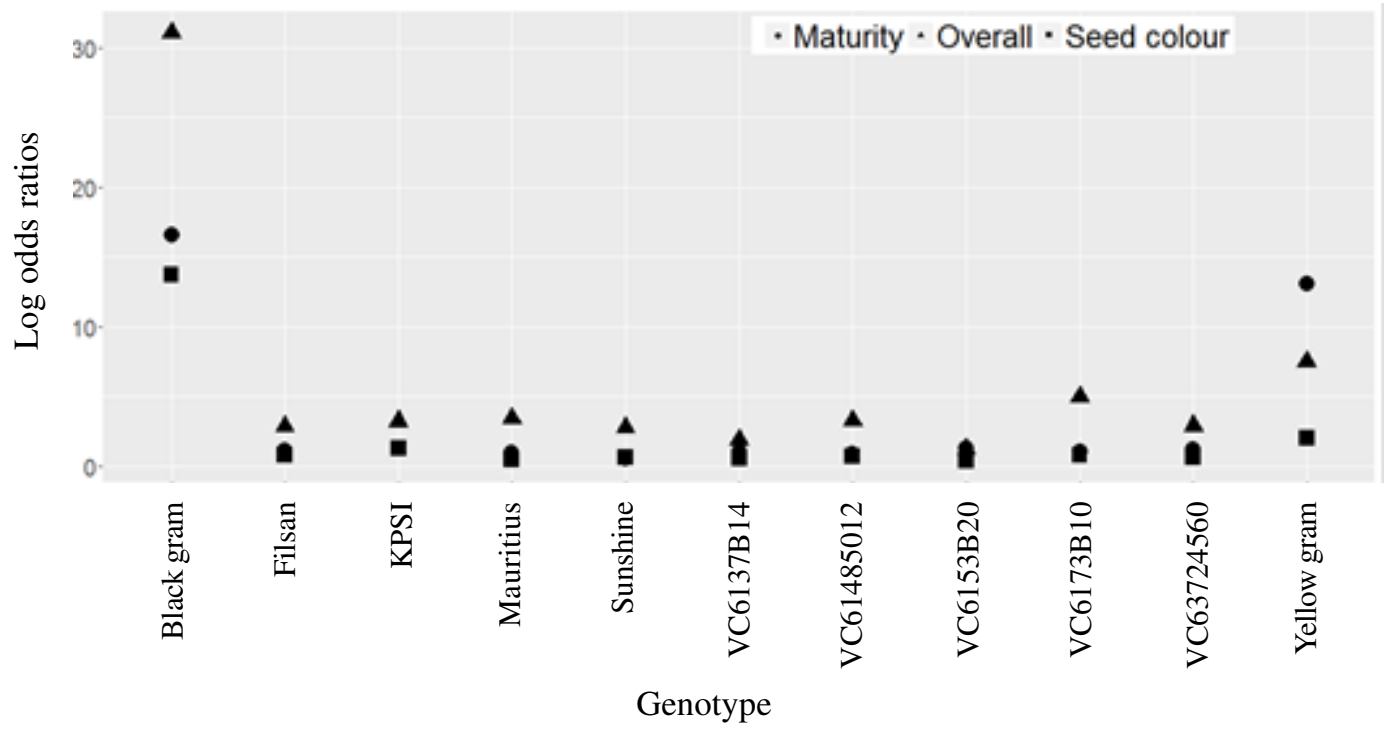

Figure 2. Mungbean genotypes comparisons based on logistic regression analysis of farmer perceptions in Uganda. Log odds ratio on the Y-axis indicates the chance of being better (very good performance for that particular trait) or worse (poor for the trait) response category. A low odds ratio indicates that the genotype is likely to be rated much better for that trait and the vice versa.

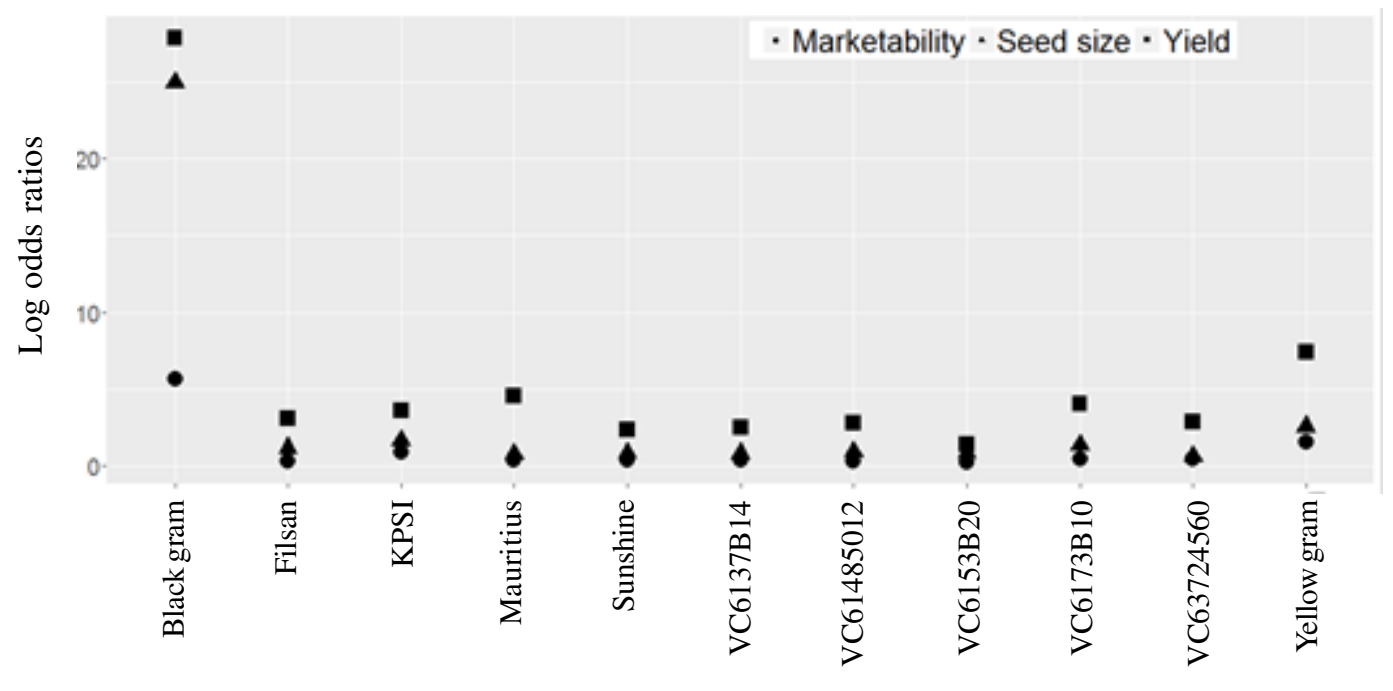

Genotype

Figure 3. Mungbean genotypes comparisons based on logistic regression analysis of farmer perceptions in Uganda. Log odds ratio on the Y-axis indicates the chance of being better (very good performance for that particular trait) or worse (poor for the trait) response category. A low odds ratio indicates that the genotype is likely to be rated much better for that trait and the vice versa. 


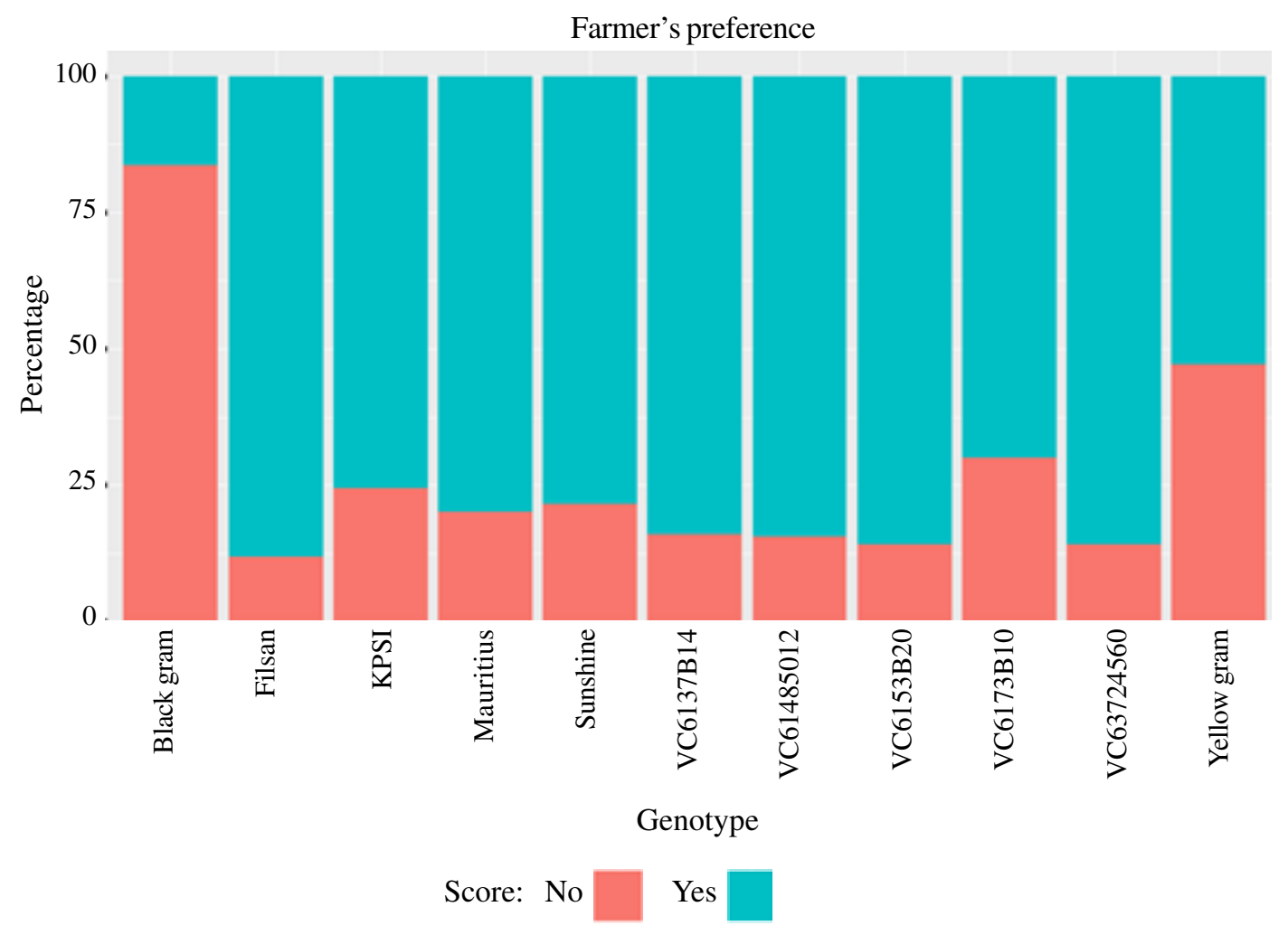

Figure 4. Mungbean genotype preferred by farmers in eastern and northern Uganda.

TABLE 3. Yield of mungbean genotypes on-farm in eastern and northern Uganda

\begin{tabular}{lc}
\hline Genotype & $\begin{array}{c}\text { Mean yield }\left(\mathrm{kg} \mathrm{ha}^{-1}\right) \\
\text { across seasons }\end{array}$ \\
\hline Blackgram & 1458.7 \\
Filsan & 644.6 \\
Kps 1 & 765.1 \\
Check & 711.1 \\
Mauritius & 551.0 \\
Sunshine & 644.9 \\
VC6137B14 & 627.4 \\
VC61485012 & 631.1 \\
VC6153B20 & 805.4 \\
VC6173B10 & 653.2 \\
VC63724560 & 688.4 \\
Yellowgram & 1035.4 \\
Mean & \\
\hline
\end{tabular}

farmers (Figs. 2 and 3). Among the preferred genotypes were Filsan and Sunshine, that had also been identified in two previous studies (Mbeyagala et al., 2015; Mbeyagala et al., 2016) as high yielding and stable across environments. Genotypes such as blackgram and yellowgram that yielded higher than all the other genotypes (Table 3), were not preferred by farmers. Blackgram and yellowgram are late maturing, have small black and yellow seeds respectively which makes them unattractive, less tasty and unmarketable by farmers. Therefore, using yield alone without farmer involvement and without the traits they consider important in varietal selection and advancement, leads to non-adoption of released varieties ( Sperling et al.,1993; Mekbib, 1997; Kitch et al., 1998). It has also 
been reported that breeders and farmers tend to evaluate and select genotypes on the basis of different traits and this mismatch in criteria often results in valuable genotypes being discarded, while the less preferred genotypes are advanced (Asfaw et al., 2012).

Asking farmers to indicate which of the new genotypes they intended to plant the following seasons further ascertained how farmers perceived the new genotypes (Fig. 4) compared to the local check. It has been reported by Kamara et al, (2010) that asking farmers to indicate genotypes that they would like to plant in their own gardens for the subsequent seasons minimises bias in any of the identified criteria.

Our observations in this study indicate that large green seeded mungbean genotypes are readily marketed and as a result farmers' preferences are strongly influenced by market forces. Large green seeded mungbean genotypes fetch a higher price than the small seeded types (Ibedo, 2014).

The lack of gender differentiation in genotype preferences shows that for mungbean improvement in Uganda, it is possible to develop a single variety that meets the preferences of both men and women. This is contrast with crops like common beans, where variety choices are strongly influenced by gender (Asfaw et al., 2012). For instance, men prefer common bean varieties that are highly marketable; while women consider varieties with excellent culinary traits such as easy to cook and taste (Asfaw et al., 2012).

\section{CONCLUSION}

Our results indicate that mungbean variety preferences in eastern and northern Uganda are greatly influenced by the market; thus, farmers seek for genotypes that give them a marketing edge. Farmers preferred genotypes with large green seeds which are known to be readily marketable at a premium prices. Therefore, mungbean genotypes with a combination of traits such as good yield, large green or greenish yellow seeds and early maturity have a higher likelihood of being accepted in the eastern and northern regions of Uganda. The selection criteria proposed by farmers will help to guide future mungbean breeding and selection of genotypes.

\section{ACKNOWLEDGEMENT}

This work was funded by the Government of Uganda (GoU), through the ATAAS World Bank Project, under the Greengram Variety Development Project (Project \# 945002). We thank National Semi Arid Resources Research Institute (NaSARRI) and National Agricultural Research Organization (NARO) for providing facilities for the work presented in this paper. The contributions of the field staff in the Dryland Legume Research Program at NaSARRI in the management of trials are acknowledged.

\section{REFERENCES}

Asfaw, A., Almekinders, C.J.M., Blair, M.W. and Struik, P.C. 2012. Participatory approach in common bean (Phaseolus vulgaris $\mathrm{L}$.) breeding for drought tolerance for southern Ethiopia. Plant Breeding 131(1):125-134.

Coe, R. 2002a. Analyzing ranking and rating data from participatory on-farm trials. In: Bellon, M.R. and Reeves, J. (Eds.), Quantitative Analysis of Data from Participatory Methods in Plant Breeding, CIMMYT, Mexico, DF. pp. 45-65.

Coe, R. 2002b. Analyzing data from participatory on-farm trials. In: Bellon, M.R. and Reeves, J. (Eds.), Quantitative Analysis of Datafrom Participatory Methods in Plant Breeding, CIMMYT, Mexico, DF. pp. 18-35.

Heuzé, V., Tran,G., Bastianelli, D. and Lebas, F. 2015. Mungbean (Vigna radiata). Feedipedia, a programme by INRA, CIRAD, AFZ and FAO. http://www. feedipedia.org/node/235. 
Ibedo, A.S. 2014. Analysis of the greengram value chain in Uganda. (MSc. Thesis). Makerere University, Kampala, Uganda. 113 pp.

IBPGR. 1980. Descriptors for mungbean. International Board for Plant Genetic Resources, (IBPGR), Rome, (Italy). 18pp.

Kamara, A.Y., Ellis-Jones, J., Ekeleme, F., Omoigui, L., Amaza, P., Chikoye, D. and Dugje, I.Y. 2010. A participatory evaluation of improved cowpea cultivars in the Guinea and Sudan savanna zones of north east Nigeria. Archives of Agronomy and Soil Science 56(3):355-370.

Kapinga, R. E., Jeremiah, S. and Rees, D. 2003. Farmer criteria for selection of sweetpotato varieties, results from Tanzania. In: Rees, D., Van Oirschot, Q. and Kapinga, R. (Eds.), Sweetpotato postharvest Assessment: Experiences from East Africa, Chattam, UK, Natural Resources Institute. pp. 9-21.

Kitch, L.W., Boukar, O., Endondo, C. and Murdock, L.L. 1998. Farmer acceptability criteria in breeding cowpea. Experimental Agriculture 34(04): 475-486.
Mbeyagala, K.E. Amayo, R. and Obuo, J.E.P. 2015. Selection for high yield and stability among introduced greengram genotypes in Uganda. Journal of Agricultural Science 7(9):154-159.

Mbeyagala, E.K., Amayo, R. and Obuo, J.E.P. 2016. Adaptation of introduced mungbean genotypes in Uganda. African Crop Science Journal 24(2):155-166.

Mekbib, F. 1997. Farmers' participation in common bean genotype evaluation: The case of eastern Ethiopia. Experimental Agriculture 33:399-408.

Mogotsi, K.K. 2006. Vigna radiata (L.) R. Wilczek. In: Brink, M. and Belay, G. (Eds.). PROTA 1: Cereals and pulses/Céréales et légumes secs. [CD-Rom]. PROTA, Wageningen, Netherlands.

R Core Team. 2016. R: A language and environment for statistical computing. $\mathrm{R}$ Foundation for Statistical Computing, Vienna, Austria. URL http://www.Rproject.org

Sperling, L., Loevinsohn, M.E. and Ntabomvura, B. 1993. Rethinking the farmer's role in plant breeding: Local bean experts and on-station selection in Rwanda. Experimental Agriculture 29:(04):509-519. 